\title{
Behavior of Fire Exposed Concrete-Filled Double Skin Steel Tubular (CFDST) Columns under Concentric Axial Loads
}

\author{
S.S Mohd Zuki ${ }^{1,2, a}$, K.K Choong ${ }^{1, b}$, J. Jayaprakash ${ }^{3, c}$ \\ and Shahiron Shahidan ${ }^{2, d}$
}

\author{
${ }^{1}$ School of Civil Engineering, Universiti Sains Malaysia (USM), Nibung Tebal, Pulau Pinang, \\ Malaysia \\ ${ }^{2}$ Deparment of Structural and Material Engineering, Faculty of Civil and Environmental Engineering, \\ Universiti Tun Hussein Onn Malaysia (UTHM), Batu Pahat, Johor, Malaysia \\ ${ }^{3}$ Deparment of Civil Engineering, The University of Nottingham Malaysia Campus, Semenyih, \\ Selangor, Malaysia \\ asharifahs@uthm.edu.my, ’cekkc@eng.usm.my, J.Jayaprakash@nottingham.edu.my, \\ dshahiron@uthm.edu.my
}

Keywords: CFDST columns, fire exposure, residual strength, concentric load, ASTM E-119 fire curve

\begin{abstract}
This paper presents the result of an experimental investigation of axial behavior of concrete-filled double skin steel tubular (CFDST) columns exposed to high temperature under the action of monotonically applied concentric axial loads. The columns were exposed to ASTM E-119 standard fire curve until $600^{\circ} \mathrm{C}$ and kept constant for two different exposure time (i.e., 60 and 90 minutes). Failure patterns and reduction in strength, ductility and stiffness of CFDST columns are reported. Factors influencing the strength, ductility and stiffness of CFDST columns during fire exposure, i.e., exposure time, temperature of concrete core and temperature of inner steel tube, are also discussed.
\end{abstract}

\section{Introduction}

Concrete-filled double skin steel tubular (CFDST) was first mentioned by Shakir-Khalil in 1990's [1]. Due to its superior performance than hollow steel structural section (HSS) and concrete-filled steel tubular (CFST) section, CFDST has been used in the legs of offshore platforms in deep water and in the structures which are subjected to ice loading [2]. Most recently, CFDST have been used in a construction of high-rise bridge piers in Japan [2,3] and as a transmission tower in China [4]. CFDST columns also have potentials to be used as columns in high-rise buildings. Therefore, many researchers have been studying this type of column at ambient temperature. However, limited studies have been found on effect of fire exposure on CFDST.

This study will focus on residual strength of CFDST columns subjected to ASTM E-119 fire curve until the temperature reaching $600^{\circ} \mathrm{C}$.

\section{Experimental Program}

Preparation of Specimens and Material Properties. Nine CFDST columns with outer and inner steel diameter of $152.4 \mathrm{~mm}$ and $101.6 \mathrm{~mm}$ respectively were cast in an upright position (Fig. 1(a)). The thickness of outer and inner steel tubes is $4 \mathrm{~mm}$ and $2 \mathrm{~mm}$, respectively. The space between the two steel tubes was filled with $30 \mathrm{~N} / \mathrm{mm}^{2}$ normal strength concrete. All columns were cured at laboratory condition together with six $100 \times 100 \times 100 \mathrm{~mm}$ cubes. Three cubes were tested after 7 days of curing and another three were tested after 28 days. The columns length are $600 \mathrm{~mm}$. Details of all nine specimens are shown in Table 1 . The naming system of specimens are as follows; the first number indicates the diameter of outer tube (i.e., 6 represent 6 inch or $152.4 \mathrm{~mm}$ in SI unit), the 
second number indicates the thickness of outer tube which is $4 \mathrm{~mm}$ and the last number indicates the maximum fire exposure time in minutes. Since there are 3 specimens per testing condition, each specimen was assigned another number (i.e., 1,2,3) after the last number to represent the number of specimens in each group. For example, 6-C4-60-1 represents the specimen with outer diameter of $152.4 \mathrm{~mm}$, thickness of $4 \mathrm{~mm}$ and fire exposure time of 60 minutes. The last number 1 denotes that it is the first specimen of the corresponding group.

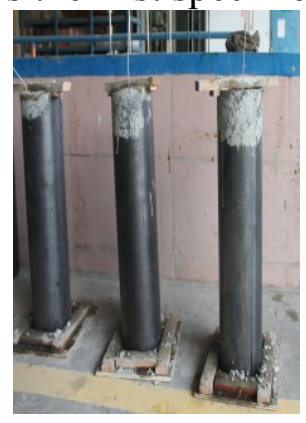

(a) Unheated specimens

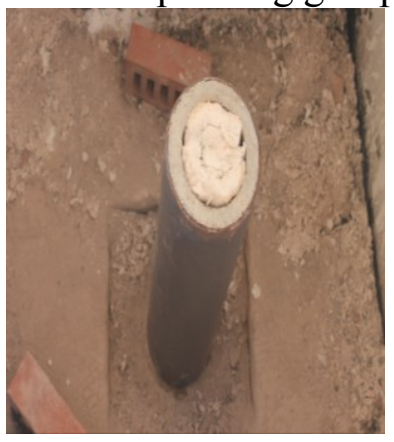

(b) Specimen during cooling down process

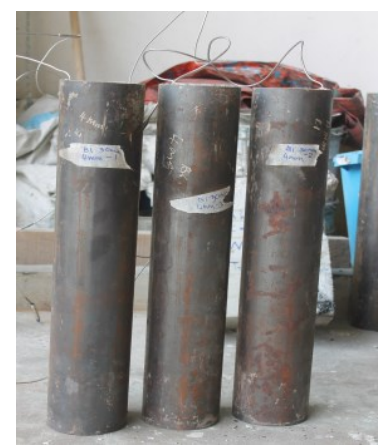

(c) Heated specimens

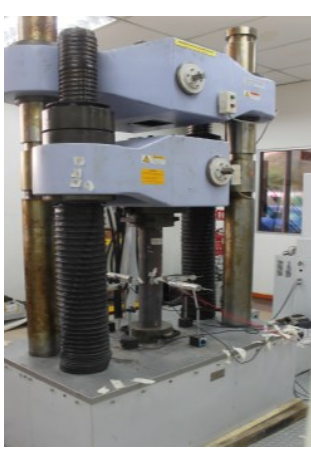

(d) Test arrangement

Fig. 1, Condition of Specimen and Test Set-Up

Table 1 Information of Tested Specimens

\begin{tabular}{|c|c|c|c|c|c|c|c|c|c|}
\hline Specimens & $\begin{array}{l}\text { No. of } \\
\text { Specimens }\end{array}$ & $\begin{array}{l}\text { Dia. of } \\
\text { Outer } \\
\text { Tube } \\
{[\mathrm{mm}]}\end{array}$ & $\begin{array}{l}\text { Thickness of } \\
\text { Outer Tube } \\
{[\mathrm{mm}]}\end{array}$ & $\begin{array}{l}\text { Dia. of } \\
\text { Inner } \\
\text { Tube } \\
{[\mathrm{mm}]}\end{array}$ & $\begin{array}{l}\text { Thickness of } \\
\text { Inner Tube } \\
{[\mathrm{mm}]}\end{array}$ & $\begin{array}{l}\text { Concrete } \\
\text { Strength at } \\
28 \text { Days } \\
{\left[\mathrm{N} / \mathrm{mm}^{2}\right]}\end{array}$ & $\begin{array}{l}\text { Tensile } \\
\text { Strength of } \\
\text { Outer Tube } \\
{\left[\mathrm{N} / \mathrm{mm}^{2}\right]}\end{array}$ & $\begin{array}{l}\text { Tensile } \\
\text { Strength of } \\
\text { Inner Tube } \\
{\left[\mathrm{N} / \mathrm{mm}^{2}\right]}\end{array}$ & $\begin{array}{l}\text { Exposure } \\
\text { Time [min] }\end{array}$ \\
\hline $\begin{array}{l}6-\mathrm{C} 4- \\
\text { Control }\end{array}$ & 3 & 152.4 & 4 & 101.6 & 2 & 38 & 430 & 566 & 0 \\
\hline 6-C4-60 & 3 & 152.4 & 4 & 101.6 & 2 & 37 & 430 & 566 & 60 \\
\hline 6-C4-90 & 3 & 152.4 & 4 & 101.6 & 2 & 35 & 430 & 566 & 90 \\
\hline
\end{tabular}

Testing Regime. The specimens were heated following ASTM E-119 [5] standard fire curve until $600^{\circ} \mathrm{C}$ in the fire furnace at Concrete Laboratory, Universiti Sains Malaysia (USM). Once the designated temperature was reached, the temperature was kept constant for two different exposure times, namely 60 and 90 minutes. In order to measure temperature of concrete core and inner steel tube, 2 thermocouple were inserted inside the concrete during casting and another thermocouple were inserted inside the steel tube before the start of heating process. The temperature of furnace, concrete core and inner steel tube were recorded during heating process. The furnace was programmed to stop automatically once the allocated exposure time was reached. The lid on top of the furnace was lifted and the specimen was left to cool down to ambient temperature as shown in Fig. 1(b).

Test Procedure. All control and heated specimens were subjected to monotonic concentric axial load until maximum failure load was reached. The specimens were tested at Construction Research Institute of Malaysia (CREAM) Laboratory using Universal Testing Machine (UTM) with maximum capacity of $2000 \mathrm{kN}$. Two vertical and two horizontal electrical strain gauges with $10 \mathrm{~mm}$ gauge length were places at mid-height of each specimens. Four Linear Variable Displacement Transducer (LVDTs) were placed at mid-height of tested specimens to measure any lateral movement in tested specimens. The set-up of the test is shown Fig. 1(d). Prior to testing, the specimens were capped with high strength epoxy. After the epoxy had hardened, the surface were grind to ensure that the contact surface of the specimens was even for better stress distribution during testing. 


\section{Result and Discussion}

Overall Behavior. Generally, there is not much difference between both heated and unheated CFDST columns. This also applies to CFDST columns that are heated for 90 minutes. Even with an extra of 30 minutes of exposure, there are no significant changes in color and appearance of the heated columns. Fig. 1(a) and (c) show the condition of unheated and heated columns. However, the color of the sandwich concrete inside steel changed from grey to whitish grey which indicates that the concrete was exposed to temperature more than $300^{\circ} \mathrm{C}$. Maximum temperature in core concrete is summarized in Table 2. Similar results were also observed by other researcher such as Short et al [6].

The failure mode of outer steel tube is an outward buckling near the tube end whereas, the inner tube failed by local inward buckling. The outward buckling of the outer steel tube is also known as elephant's foot buckling which occurs normally in HSS especially those with small diameter-to-thickness ratio. There is no sign of global buckling in the tested specimens which is typically associated with failure behavior of long and slender columns. This means that all tested specimens can be categorized as short columns. As for concrete, the failure mode is crushing of concrete as a result of local buckling of the outer steel. The local buckling of both steel tubes and the crushing of concrete are more prominent in specimens exposed to 90 minutes of fire exposure time compared with those of 60 minute exposure time and control specimens. This is most likely due to the higher reduction of strength of all three components of CFDST columns after being exposed for a longer duration.

Table 2 Summary of Tested Specimens

\begin{tabular}{|l|l|l|l|l|l|l|l|}
\hline Specimens & $\begin{array}{l}\text { Core } \\
\text { Concrete } \\
\text { Temp. } \\
{\left[{ }^{\circ} \mathrm{C}\right]}\end{array}$ & $\begin{array}{l}\text { Inner Steel } \\
\text { Temp. }\left[{ }^{\circ} \mathrm{C}\right]\end{array}$ & $\begin{array}{l}\text { Ultimate } \\
\text { Load }[\mathrm{kN}]\end{array}$ & $\begin{array}{l}\text { Disp. at } \\
\text { Ultimate } \\
\text { Strength } \\
{[\mathrm{mm}]}\end{array}$ & $\begin{array}{l}\text { Secant } \\
\text { Stiffness } \\
{[\mathrm{kN} / \mathrm{mm}]}\end{array}$ & $\begin{array}{l}\text { Strength } \\
\text { Reduction } \\
{[\%]}\end{array}$ & $\begin{array}{l}\text { Stiffness } \\
\text { Reduction } \\
{[\%]}\end{array}$ \\
\hline 6-C4-Control & - & - & 1402 & 6.98 & 203 & - & - \\
\hline 6-C4-60 & 514 & 508 & 1292 & 7.22 & 180 & 7.8 & 11.3 \\
\hline 6-C4-90 & 557 & 550 & 1199 & 9.26 & 130 & 14.5 & 36.0 \\
\hline
\end{tabular}

Temperature Distribution. Fig. 2 shows temperature distribution of one of the specimens from group 6-C4-60 and 6-C4-90. The furnace temperature measured from 4 thermocouples inside the furnace appears to be unstable. However, according to tolerances given in ASTM E-119 [5], this value is still acceptable. From both time-temperature curves shown in Fig. 2, there is a stable phase of the temperature in between 100 and $200^{\circ} \mathrm{C}$. This phase is most probably instigated by vaporizing process of water into gases that occurred at temperature around $100^{\circ} \mathrm{C}$. During this phase, the heat is used to change the state of water into gases rather than to elevate the temperature. This phenomena is also observed by other researchers such as [7] and [8].

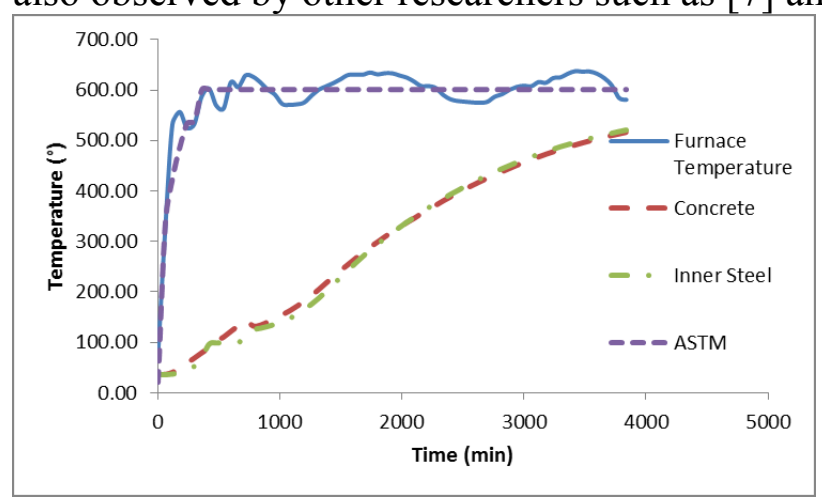

(a)

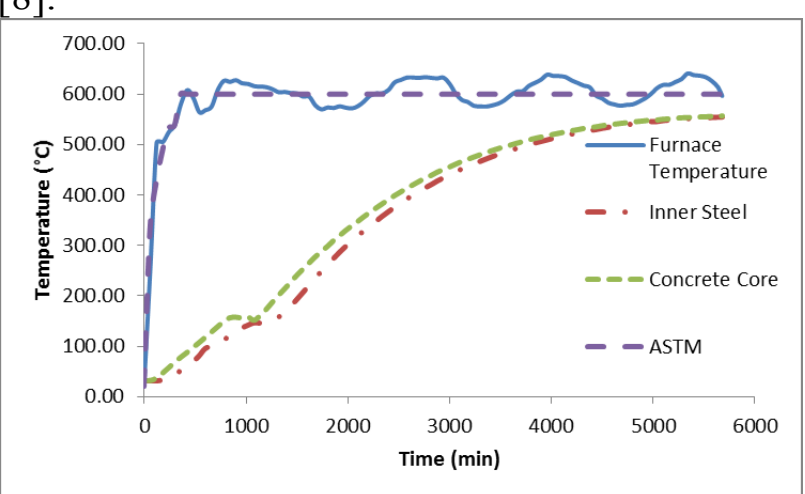

(b)

Fig. 2, Temperature Distribution of (a) 6-C4-60 and (b) 6-C4-90 
Effect of Fire Exposure on Strength, Stiffness and Ductility. According to ASTM E-119 [5], the critical temperature of steel columns is $538^{\circ} \mathrm{C}$. Critical temperature is defined as temperature where steel loses $50 \%$ of its ambient temperature strength. However, in this study, CFDST columns were exposed to temperature higher than the critical temperature for 60 and 90 minutes, i.e., $600^{\circ} \mathrm{C}$. From Table 2 and Fig. 3, the strength reduction of CFDST columns is only $7.8 \%$ and $14.5 \%$ from its ambient temperature strength (control). These reductions are still far from 50\% reduction stated in ASTM E-119 [5] even though the exposure time exceeded 90 minutes with no protection. The results show that CFDST columns can still carry almost $85 \%$ of loads even after exposure at $600^{\circ} \mathrm{C}$ for 90 minutes. Low reduction of strength in CFDST columns without fire protection is due to the contribution of concrete that acts as protection layer to inner steel tube. The temperature of inner steel tube is only $508^{\circ} \mathrm{C}$ for 60 minutes and $550^{\circ} \mathrm{C}$ for 90 minutes exposure time when the test ended. Even though the temperature of inner steel tube of 6-C4-90 exceeded the critical temperature of the steel, it reached $538^{\circ} \mathrm{C}$ only after 79 minutes of fire exposure (Fig. 2). Therefore, it can still carry load until the ends of fire course.

Secant stiffness of CFDST columns can be calculated by dividing ultimate load with displacement at ultimate load [9]. As can be seen in Table 2 and Fig. 3, the secant stiffness reduced from 100\% at ambient temperature to $11.3 \%$ and $36.0 \%$ after 60 and 90 minutes exposure time, respectively. The stiffness of fire exposed columns is expected to be lower than control specimens due to the deterioration of the all three elements in the composite column, i.e., outer steel, inner steel and concrete. After being exposed to fire, there are changes in both physical and mechanical properties of steel and concrete leading to reduction in stiffness of the materials.

Based on stress-strain curves shown in Fig. 4, it is evident that ductility of CFDST columns slightly decreased. However, the reduction in ductility is very small and can be neglected. As mentioned before, the small reduction of ductility is caused by the presence of concrete that acts as heat sink thus protecting inner steel tube from suffering severe damage due to fire exposure. Unlike outer steel tube that was directly exposed to fire, the damaged caused by fire is more severe compared to concrete and inner steel tube. The temperature of core concrete after 60 and 90 minutes of fire exposure is $514^{\circ} \mathrm{C}$ and $557^{\circ} \mathrm{C}$, respectively. The onset of concrete losing its ambient temperature strength is at temperature of $300^{\circ} \mathrm{C}$ to $400^{\circ} \mathrm{C}$. Based on Fig. 2 , it is observed that this onset only begins after 30 to 40 minutes of exposure. Therefore, concrete is still able to carry load and at the same time act as protection layer to inner steel tube thus maintaining structural integrity of CFDST columns.

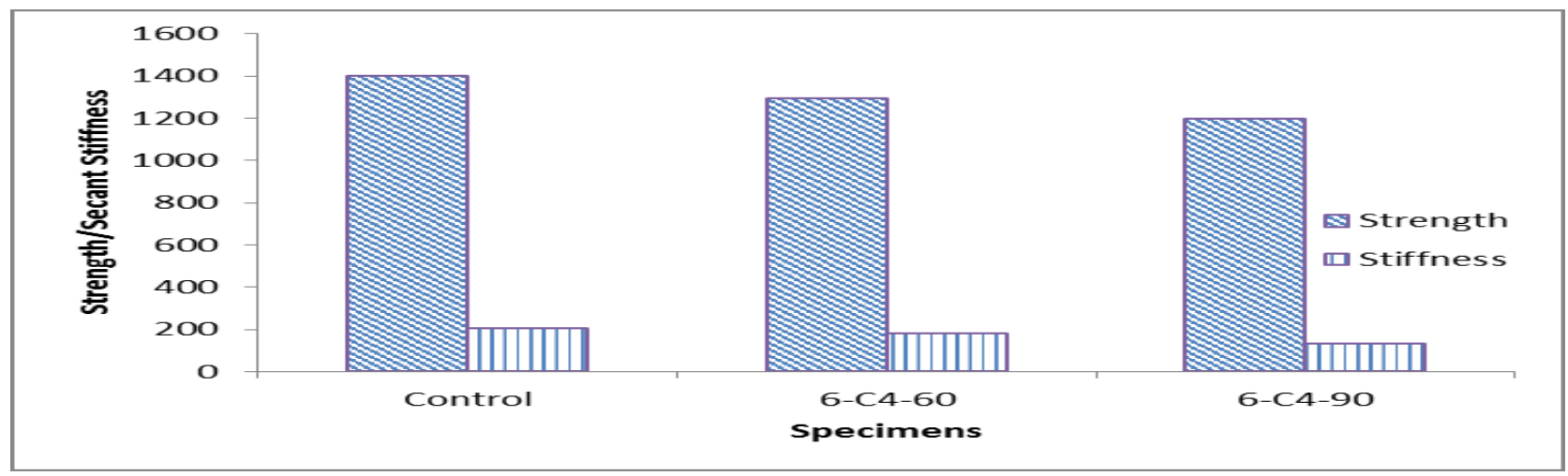

\section{Conclusion}

Fig. 3, Strength and Secant Stiffness of CFDST Columns

From the above discussion, the following conclusions can be drawn:

1) The strength reduction of fire exposed CFDST columns is only $7.8 \%$ for 60 minutes and $14.5 \%$ for 90 minutes fire exposure at $600^{\circ} \mathrm{C}$. The percentage is still far from the $50 \%$ strength reduction expected once the steel reached critical temperature of $538^{\circ} \mathrm{C}$ as stated in ASTM E-119 [5]. 
2) The reduction in secant stiffness is $11.3 \%$ and $36.9 \%$ for 60 and 90 minutes fire exposure at $600^{\circ} \mathrm{C}$, respectively. As for ductility, the reduction can be considered as insignificant. Both reductions are as expected for fire exposed CFDST columns.

3) The presence of concrete in between outer and inner steel tube is proven to be a great advantages to the CFDST columns since concrete can act as heat sink and protective layer to the inner tube.

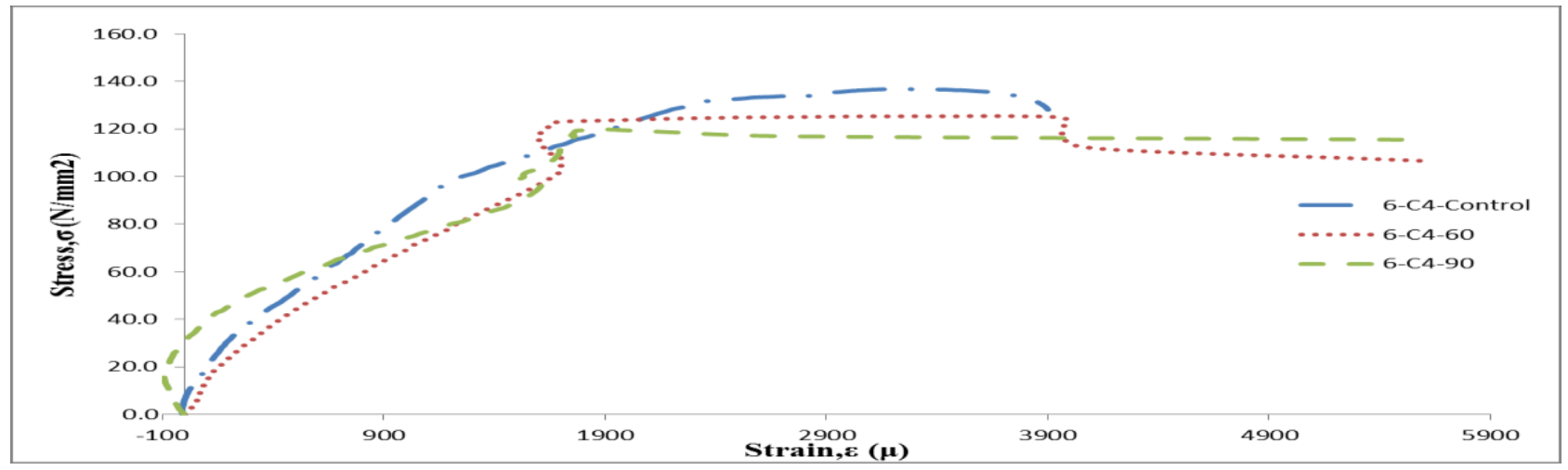

Fig. 4, Stress-Strain Curves of Control and Heated CFDST Columns

\section{Acknowledgement}

The authors are grateful for the financial and technical support provided by Universiti Sains Malaysia (USM). The authors also extend sincere gratitude to Ministry of Education Malaysia and Universiti Tun Hussein Onn Malaysia (UTHM).

\section{References}

[1] H. Shakir-Khalil, Composite columns of double-skinned shells Journal Constructional Steel Research Vol. 19 (1991), pp.133-152

[2] X.L Zhao and R. Grzebieta, Strength and ductility of concrete filled double skin (SHS inner and SHS outer) tubes Thin-Walled Structure Vol. 40 (2002), pp.199-213

[3] X.L Zhao, B. Han and R.H Grzebieta, Plastic mechanism analysis of concrete-filled double-skin (SHS inner and SHS outer) stub columns Thin-Walled Structure Vol. 40 (2002), pp. 815-33

[4] W. Li, L.H Han, Q.X Ren and X.L Zhao, Behavior and calculation of tapered CFDST columns under eccentric compression Journal of Constructional Steel Research Vol. 83 (2013), pp. $127-136$

[5] ASTM 2010, ASTM E119-11: Standard Test Methods for Fire Tests of Building Construction and Materials. 2010

[6] N. Short, J. Purkiss and S. Guise, Assessment of fire damaged concrete using colour image analysis Construction and Building Materials Vol. 15 (2001), pp. 9-15

[7] H. Lu, X.L Zhao and L.H Han, Testing of self-consolidating concrete-filled double skin tubular stub columns exposed to fire Journal of Constructional Steel Research Vol. 66 (2010), pp. 1069-1080

[8] H. Lu, L.H Han and X.L Zhao, Fire performance of self-consolidating concrete filled double skin steel tubular columns: Experiments Fire and Safety Journal Vol. 45 (2010), pp. 106-115

[9] M. Yaqub and C.G Bailey, Repair of fire damaged circular reinforced concrete columns with FRP composites Construction and Building Materials Vol. 25 (2011), pp. 359-370 